\title{
KERAGAAN KONSUMSI IKAN DI INDONESIA TAHUN 2005-2011
}

\author{
(Fish Consumption in Indonesia Year of 2005-2011) \\ Yayuk Farida Baliwati ${ }^{1 *}$ dan Yulmiaris Dwi Okto Putri ${ }^{1}$ \\ 'Departemen Gizi Masyarakat, Fakultas Ekologi Manusia (FEMA), Institut Pertanian Bogor, \\ Jl. Raya Darmaga, Bogor 16880
}

\begin{abstract}
The objective of this study was to analyze fish consumption in Indonesia 2005-2011. Data used in this study was based on the National Social and Economic Survey (SUSENAS). The study showed average national fish consumption $26.04 \mathrm{~kg} /$ capita/year, with average growth rate $0.05 \%$ per year. Fish consumption was higher in urban (26.51 kg/capita/year) than rural area $(25.69 \mathrm{~kg} /$ capita/year). Contribution of fresh fish and processed fish was higher in urban than rural area $(63.0 \%$ and $14.0 \%)$. Processed food containing fish was higher in rural (8.30 kg/capita/year) than urban area $(6.09 \mathrm{~kg} /$ capita/year). Low expenditure households consumed fish lower than the high expenditure. Recommendation of fish consumption is $32.70 \mathrm{~kg} /$ capita/year or $12.89 \mathrm{~g}$ protein/capita/day. The National fish requirement is projected 8.10 million tons at 2015.
\end{abstract}

Keywords: fish consumption, level of expenditure, rural, urban

\begin{abstract}
ABSTRAK
Tujuan dari penelitian ini adalah untuk menganalisis keragaan konsumsi ikan di Indonesia tahun 2005-2011. Data yang digunakan adalah Survey Sosial dan Ekonomi Nasional (SUSENAS). Hasil penelitian menunjukkan rata-rata konsumsi ikan nasional adalah $26.04 \mathrm{~kg} / \mathrm{kapita} /$ tahun, dengan rata-rata laju pertumbuhan $0.05 \%$ per tahun. Konsumsi ikan lebih tinggi di wilayah perkotaan $(26.51 \mathrm{~kg} / \mathrm{kapita} / \mathrm{tahun})$ dibandingkan pedesaan ( $25.69 \mathrm{~kg} / \mathrm{kapita} / \mathrm{tahun})$. Konsumsi ikan dari ikan segar dan ikan olahan lebih tinggi di perkotaan dibandingkan pedesaan (63.0\% dan $14.0 \%)$. Konsumsi ikan dari pangan olahan lebih tinggi di pedesaan $(8.30 \mathrm{~kg} / \mathrm{kapita} /$ tahun) dibandingkan perkotaan $(6.09 \mathrm{~kg} / \mathrm{kapita} / \mathrm{tahun})$. Masyarakat dengan golongan pengeluaran rendah mengonsumsi ikan dengan jumlah yang lebih sedikit daripada masyarakat golongan pengeluaran tinggi. Rekomendasi konsumsi ikan adalah $32.70 \mathrm{~kg} / \mathrm{kapita} /$ tahun setara dengan $12.89 \mathrm{~g}$ protein/kapita/hari. Kebutuhan ikan nasional untuk dikonsumsi diproyeksikan mencapai 8.10 juta ton pada tahun 2015 .
\end{abstract}

Kata kunci: konsumsi ikan, pedesaan, perkotaan, tingkat pengeluaran

"Korespondensi: Departemen Gizi Masyarakat, Fakultas Ekologi Manusia (FEMA), Institut Pertanian Bogor, Jl. Raya Darmaga, Bogor 16880; Email: yayukgm@yahoo.com 


\section{PENDAHULUAN}

Pengembangan subsektor peternakan selama 10 tahun terakhir menunjukkan hasil yang cukup nyata dalam berbagai aspek, di antaranya produksi daging meningkat dari 1508200 ton menjadi 2613 200 ton atau naik $4.0 \%$ per tahun, telur meningkat dari 736000 ton menjadi 1149000 ton atau naik $5.6 \%$ per tahun, dan susu meningkat dari 433400 ton menjadi 550000 ton atau naik $2.7 \%$ per tahun. Dengan tingkat pencapaian produksi tersebut maka tingkat konsumsi masyarakat, khususnya protein hewani asal ternak, meningkat dari $4.19 \mathrm{~g}$ menjadi $5.46 \mathrm{~g} / \mathrm{kapita} / \mathrm{hari}$ atau naik $3.1 \%$ per tahun (Kusnadi 2008).

Potensi sumber daya pangan hewani yang terbesar di Indonesia berasal dari perikanan. Menurut Dahuri (2003), Indonesia merupakan negara yang memiliki sumber daya perikanan dengan keanekaragaman spesies tertinggi di dunia. Pengkajian stok ikan di perairan Indonesia menunjukkan bahwa potensi lestari sumber daya perikanan Indonesia mencapai 6.4 juta ton/tahun. Dengan sumber daya tersebut, seharusnya bahan pangan khususnya protein hewani dapat tersedia dan dimanfaatkan dengan baik sehingga tidak terjadi masalah kekurangan gizi.

Ikan merupakan sumber protein dan vitamin yang baik, termasuk vitamin A dan D (Speedy 2003). Ikan merupakan sumber utama asam lemak tak jenuh rantai panjang omega-3, eicosapentaenoic acid (EPA) dan docosahexaenoic acid (DHA), yang sangat penting bagi fungsi dan struktur otak (Devore et al. 2009). Sebagai sumber penting asam lemak EPA dan DHA, konsumsi ikan juga dapat menurunkan risiko penyakit kardiovaskular. Untuk mencegah kematian akibat penyakit kardiovaskuler, American Heart Association merekomendasikan konsumsi ikan kurang lebih dua kali seminggu (Van Gelder et al. 2007). Dari segi budaya dan agama, hasil penelitian Reis dan Hibbeln (2006) menunjukkan bahwa ritual konsumsi ikan secara psikologi dapat membantu seseorang dalam memperoleh status harmoni internal, demikian pula dengan perilaku sosial. Jika dihubungkan dengan simbol religi sebagai salah satu identitas budaya, konsumsi ikan meningkatkan perilaku yang secara signifikan mendukung aspek budaya.

Selama setengah abad terakhir, konsumsi ikan secara internasional dapat dilihat sukses besar, ratarata konsumsi ikan per kapita meningkat dari 9.90 kg (setara berat ikan segar) pada tahun 1960-an menjadi $18.40 \mathrm{~kg}$ tahun 2009 . Meskipun demikian, terdapat perbedaan antar wilayah; konsumsi terendah adalah di Afrika (9.10 kg/kapita), diikuti oleh Amerika Latin dan Karibia $9.90 \mathrm{~kg}$, Asia $20.70 \mathrm{~kg}$, Eropa $22.00 \mathrm{~kg}$, Amerika Utara $24.10 \mathrm{~kg}$, dan Oseania $24.60 \mathrm{~kg}$. Walaupun konsumsi ikan meningkat di negara-negara berkembang dan negara LIFDC (Low-
Income Food Deficit Countries), tingkat konsumsi ikan masih di bawah negara maju (Muir 2013).

Perhitungan konsumsi ikan yang dilakukan oleh Kementerian Kelautan dan Perikanan (KKP) masih belum memperhitungkan beberapa bahan pangan yang tercatat dalam SUSENAS yang dapat berkontribusi terhadap tingkat konsumsi ikan secara keseluruhan. Bahan pangan tersebut diantaranya terasi, kerupuk, nasi campur/nasi rames, dan ikan (goreng, bakar, pindang, dsb).

Berdasarkan permasalahan di atas, peneliti tertarik untuk mengkaji angka konsumsi ikan di Indonesia dengan menambahkan bahan pangan yang belum diperhitungkan oleh Kementerian Kelautan dan Perikanan. Selain itu, dengan mengkaji angka konsumsi ikan di Indonesia diharapkan dapat diketahui pula rekomendasi konsumsi ikan bagi masyarakat.

Tujuan umum penelitian ini adalah untuk menganalisis keragaan konsumsi ikan di Indonesia tahun 2005-2011. Tujuan khusus dari penelitian ini adalah untuk menganalisis konsumsi ikan berdasarkan wilayah, golongan pengeluaran, dan rekomendasi konsumsi ikan.

\section{METODE}

\section{Desain, Tempat, dan Waktu}

Penelitian ini menggunakan data sekunder yang berkaitan dengan konsumsi ikan di Indonesia yang diperoleh dari berbagai instansi terkait. Penelitian dilakukan bulan Juni sampai September 2012 di Bogor, Jawa Barat.

\section{Jenis dan Cara Pengumpulan Data}

Subjek dalam penelitian ini adalah mahasiswa IPB yang terdaftar sebagai pengurus Badan Eksekutif Mahasiswa IPB (BEM-IPB) dan merupakan mahasiswa angkatan 2009-2011. Kriteria inklusi subjek adalah tinggal di Bogor secara mandiri, yaitu tidak tinggal bersama orang tua atau keluarga, dan bukan merupakan mahasiswa Program Studi Ilmu Gizi ataupun Ilmu Teknologi Pangan. Subjek dipilih secara purposif dan proporsional berdasarkan populasi di masingmasing wilayah BEM tingkat fakultas/pusat, yang secara keseluruhan berjumlah 10 wilayah. Jumlah subjek dalam penelitian ini adalah 86 mahasiswa.

\section{Jenis dan Cara Pengumpulan Data}

Jenis data yang digunakan dalam penelitian ini seluruhnya berupa data sekunder. Data yang digunakan adalah data konsumsi ikan dari SUSENAS berdasarkan wilayah dan golongan pengeluaran.

\section{Pengolahan dan Analisis Data}

Data yang diperoleh diolah menggunakan program Microsoft Excel. Analisis dilakukan secara deskriptif untuk menunjukkan keragaan konsumsi ikan, konsumsi ikan berdasarkan karakteristik 
wilayah (perkotaan atau pedesaan), serta konsumsi ikan berdasarkan kelompok pengeluaran. Analisis rekomendasi konsumsi ikan dilakukan secara deskriptif berdasarkan kontribusi konsumsi ikan terhadap konsumsi pangan hewani sesuai dengan Angka Kecukupan Energi (AKE).

Data konsumsi ikan SUSENAS diolah berdasarkan faktor konversi ikan olahan. Faktor konversi ikan olahan yang digunakan berasal dari konversi ikan segar ke ikan awetan dari Neraca Bahan Makanan (NBM) dan faktor konversi hasil kajian tim IPB-KKP. Selanjutnya, setelah dilakukan konversi ke bentuk ikan segar, dilakukan perhitungan konsumsi tidak tercatat sebesar $17.0 \%$ dari konsumsi setara ikan segar. Konsumsi tidak tercatat diperlukan karena angka konsumsi yang tercantum dalam SUSENAS diduga belum mencakup konsumsi keseluruhan. Angka konversi tidak tercatat diperoleh dari persentase penggunaan ikan pada industri pengolahan ikan terhadap konsumsi setara ikan segar dibandingkan dengan persentase konsumsi ikan dari terasi dan kerupuk terhadap konsumsi setara ikan segar. Terdapat selisih yang cukup besar antara penggunaan ikan untuk industri dengan konsumsi ikan dari terasi dan kerupuk sehingga diperoleh angka koreksi untuk konsumsi tidak tercatat.

Total konsumsi ikan dihitung berdasarkan penjumlahan konsumsi setara ikan segar dan konsumsi tidak tercatat. Komposisi konsumsi ikan terhadap konsumsi pangan hewani sesuai kandungan energi dihitung berdasarkan persentase konsumsi energi dari ikan terhadap konsumsi energi dari pangan hewani. Rekomendasi konsumsi ikan/kapita/hari dihitung berdasarkan peresentase konsumsi energi dari ikan terhadap komposisi ideal energi dari konsumsi pangan hewani. Rekomendasi konsumsi ikan (kg/ kapita/tahun) dihitung dengan mengalikan rekomendasi konsumsi ikan/kapita/hari dengan jumlah hari dalam setahun. Perhitungan sasaran atau proyeksi konsumsi ikan untuk tahun-tahun berikutnya adalah dengan interpolasi linier. Perhitungan kebutuhan ikan untuk dikonsumsi dalam satuan ton/tahun dihitung berdasarkan proyeksi jumlah penduduk.

\section{HASIL DAN PEMBAHASAN}

\section{Konsumsi Ikan berdasarkan Wilayah}

Konsumsi ikan berdasarkan wilayah (Tabel 1) diketahui mengalami penurunan pada tahun 2006 dan 2009 baik di pedesaan, perkotaan maupun nasional. Penurunan konsumsi ikan diduga terjadi karena pada masa krisis terjadi penyesuaian strategi pemenuhan kebutuhan pangan sehingga konsumsi pangan hewani dikurangi.

Konsumsi ikan di wilayah perkotaan lebih tinggi daripada konsumsi ikan di wilayah pedesaan. Hal ini sesuai dengan hasil penelitian Adam (2007) yang menyatakan bahwa konsumsi ikan di daerah perkotaan lebih tinggi daripada di daerah pedesaan karena rumah tangga di daerah perkotaan memiliki kesadaran akan kandungan gizi ikan yang tinggi, tingkat pendapatan yang lebih tinggi, dan preferensi protein yang lebih beragam dibandingkan di daerah pedesaan. Laju pertumbuhan konsumsi ikan rata-rata adalah $0.05 \%$ yang menunjukkan bahwa perubahan konsumsi ikan di Indonesia cenderung lambat.

Secara umum, konsumsi ikan terbanyak berasal dari ikan segar (Gambar 1). Komposisi konsumsi ikan didominasi oleh kelompok ikan segar di tingkat nasional maupun pada wilayah pedesaan dan perkotaan. Konsumsi ikan dari ikan segar secara nasional mencapai 62.1\%. Di perkotaan, konsumsi ikan segar sedikit lebih banyak daripada di pedesaan. Sebaliknya, konsumsi ikan olahan lebih banyak di pedesaan daripada perkotaan. Konsumsi ikan olahan di pedesaan mencapai sepertiga dari konsumsi ikan, sementara di pedesaan konsumsi ikan olahan hanya sekitar seperempat dari konsumsi ikan. Konsumsi ikan dari makanan jadi mencapai $10.1 \%$ dari konsumsi ikan. Namun demikian, konsumsi ikan dari makanan jadi di perkotaan (14.0\%) lebih tinggi dibandingkan dengan di pedesaan (6.4\%).

\section{Konsumsi Ikan Segar}

Rata-rata konsumsi ikan segar nasional adalah $16.16 \mathrm{~kg} / \mathrm{kapita} /$ tahun. Rata-rata konsumsi ikan

Tabel 1. Konsumsi Ikan berdasarkan Wilayah

\begin{tabular}{ccccccc}
\hline \multirow{2}{*}{ Tahun } & \multicolumn{2}{c}{ Nasional } & \multicolumn{2}{c}{ Pedesaan } & \multicolumn{2}{c}{ Perkotaan } \\
\cline { 2 - 7 } & Kg/kap/th & Laju (\%) & Kg/kap/th & Laju (\%) & Kg/kap/th & Laju (\%) \\
\hline 2005 & 26.34 & - & 26.40 & - & 26.46 & - \\
2006 & 25.23 & -4.21 & 24.36 & -7.73 & 26.21 & -0.94 \\
2007 & 25.88 & 2.58 & 25.15 & 3.23 & 26.65 & 1.67 \\
2008 & 27.11 & 4.75 & 27.00 & 7.36 & 27.23 & 2.17 \\
2009 & 25.18 & -7.12 & 24.87 & -7.87 & 25.5 & -6.33 \\
2010 & 26.25 & 4.25 & 25.96 & 4.35 & 26.56 & 4.15 \\
2011 & 26.27 & 0.08 & 26.06 & 0.39 & 26.95 & 1.47 \\
Rata-rata & 26.04 & 0.05 & 25.69 & -0.05 & 26.51 & 0.37 \\
\hline
\end{tabular}




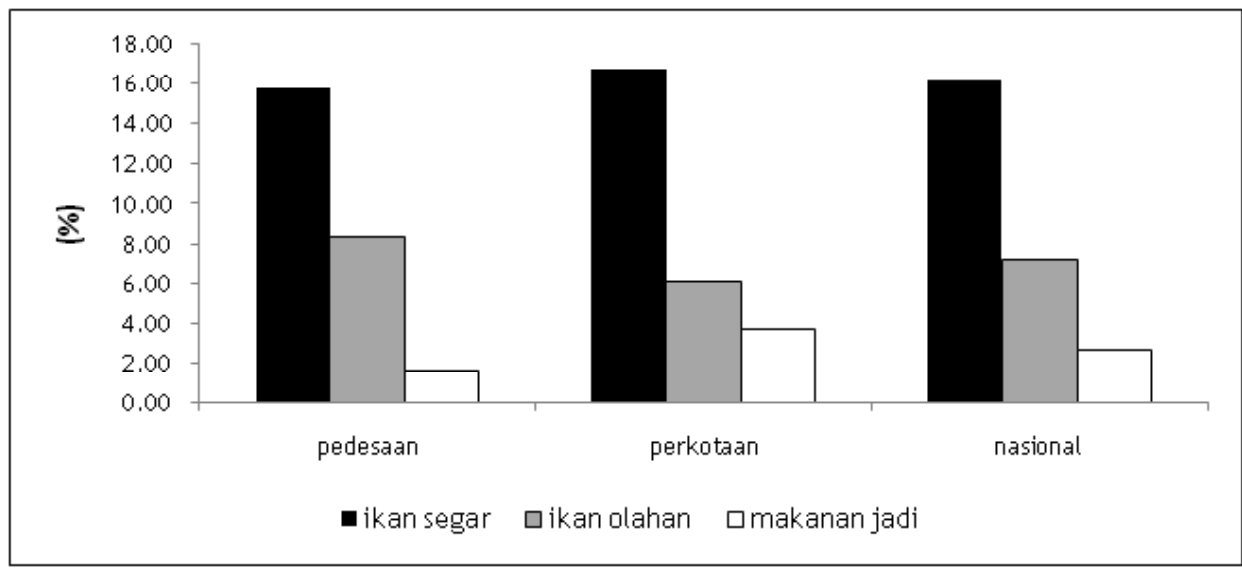

Gambar 1. Komposisi Konsumsi Ikan Aktual berdasarkan Wilayah

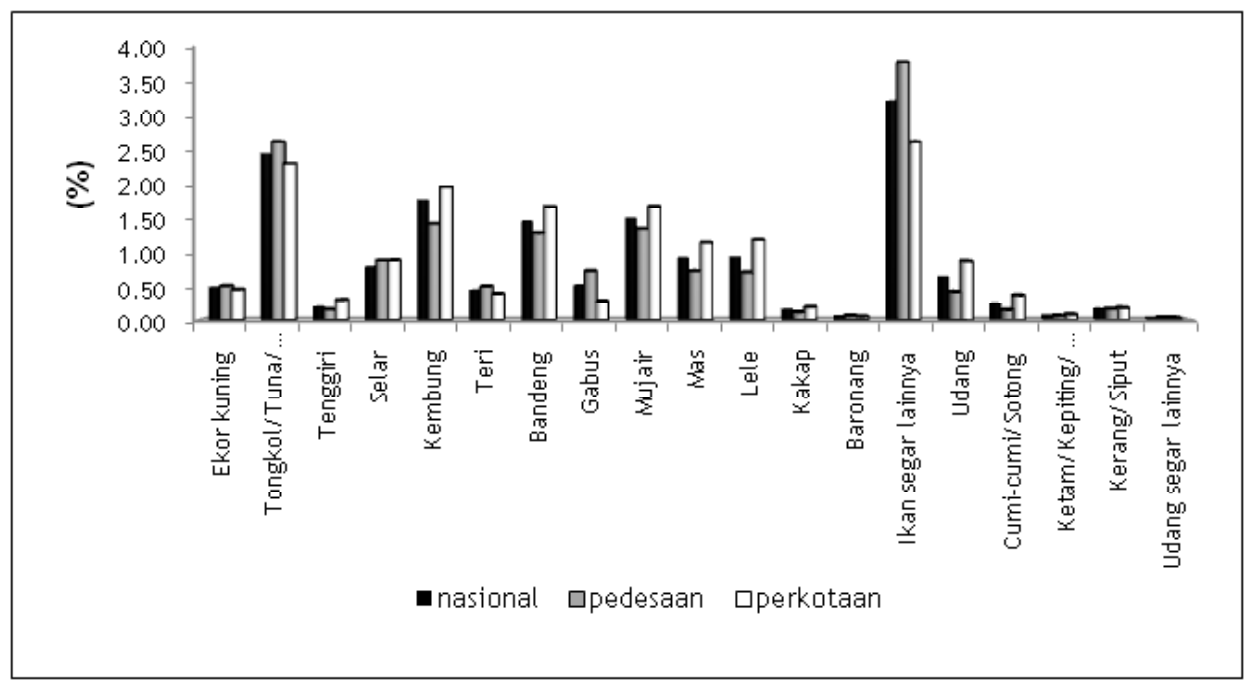

Gambar 2. Konsumsi Berbagai Jenis Ikan Segar (kg/kapita/tahun)

segar di pedesaan adalah $15.74 \mathrm{~kg} / \mathrm{kapita} / \mathrm{tahun}$. Rata-rata konsumsi ikan segar di perkotaan adalah $16.71 \mathrm{~kg} / \mathrm{kapita} /$ tahun. Jenis ikan yang paling banyak dikonsumsi adalah jenis ikan lainnya, baik di pedesaan, perkotaan maupun nasional. Sementara, jenis ikan yang paling sedikit dikonsumsi adalah baronang serta udang dan hewan air lainnya segar (Gambar 2).

Jenis ikan lainnya yang banyak dikonsumsi di wilayah pedesaan maupun perkotaan menunjukkan bahwa masih terdapat jenis-jenis ikan yang dikonsumsi masyarakat namun tidak tercatat dalam SUSENAS. Dari Gambar 2 diketahui bahwa udang sebagai salah satu unggulan ekspor perikanan Indonesia masih dikonsumsi dalam jumlah yang sedikit, khususnya di pedesaan. Jenis ikan yang dikonsumsi lebih dari satu kg/kapita/tahun diataranya adalah ikan lainnya, ikan tongkol/tuna/cakalang, ikan kembung, ikan mujair, dan ikan bandeng (Tabel 2 ).

Jenis-jenis ikan segar yang dikonsumsi lebih dari satu kg/kapita/tahun menunjukkan kecenderungan konsumsi masyarakat, baik di pedesaan maupun perkotaan. Konsumsi ikan segar tertinggi adalah jenis ikan lainnya. Hal ini dapat terjadi ka- rena beragamnya jenis ikan segar yang dikonsumsi masyarakat yang belum terangkum dalam data SUSENAS. Rata-rata konsumsi ikan lainnya mencapai 3.24 kg/kapita/tahun.

\section{Konsumsi Ikan Olahan}

Konsumsi ikan olahan menunjukkan jenis ikan olahan yang banyak dikonsumsi adalah ikan teri awetan (Gambar 3). Jenis ikan olahan dengan konsumsi terendah adalah cumi-cumi/sotong awetan. Total konsumsi ikan olahan rata-rata adalah 7.25 kg/kapita/tahun. Rata-rata konsumsi ikan olahan di pedesaan $(8.30 \mathrm{~kg} / \mathrm{kapita} /$ tahun) lebih tinggi daripada rata-rata konsumsi ikan olahan di perkotaan (6.09 kg/kapita/tahun). Secara nasional, ikan olahan yang paling banyak dikonsumsi adalah ikan teri awetan dengan rata-rata sebesar $1.69 \mathrm{~kg} / \mathrm{kapita} / \mathrm{ta}-$ hun. Sementara, jenis ikan olahan dengan konsumsi terendah adalah cumi-cumi/sotong awetan dengan rata-rata sebesar $0.04 \mathrm{~kg} / \mathrm{kapita} /$ tahun.

Jenis ikan olahan dengan konsumsi tertinggi di pedesaan adalah ikan awetan lainnya $(2.00 \mathrm{~kg} /$ kapita/tahun) sedangkan di perkotaan adalah ikan teri awetan (1.36 kg/kapita/tahun). Jenis ikan olah- 
Tabel 2. Perkembangan Konsumsi Ikan Segar Berdasarkan Jenis Ikan Segar yang Dikonsumsi Lebih Dari $1 \mathrm{~kg} / \mathrm{kapita} /$ tahun

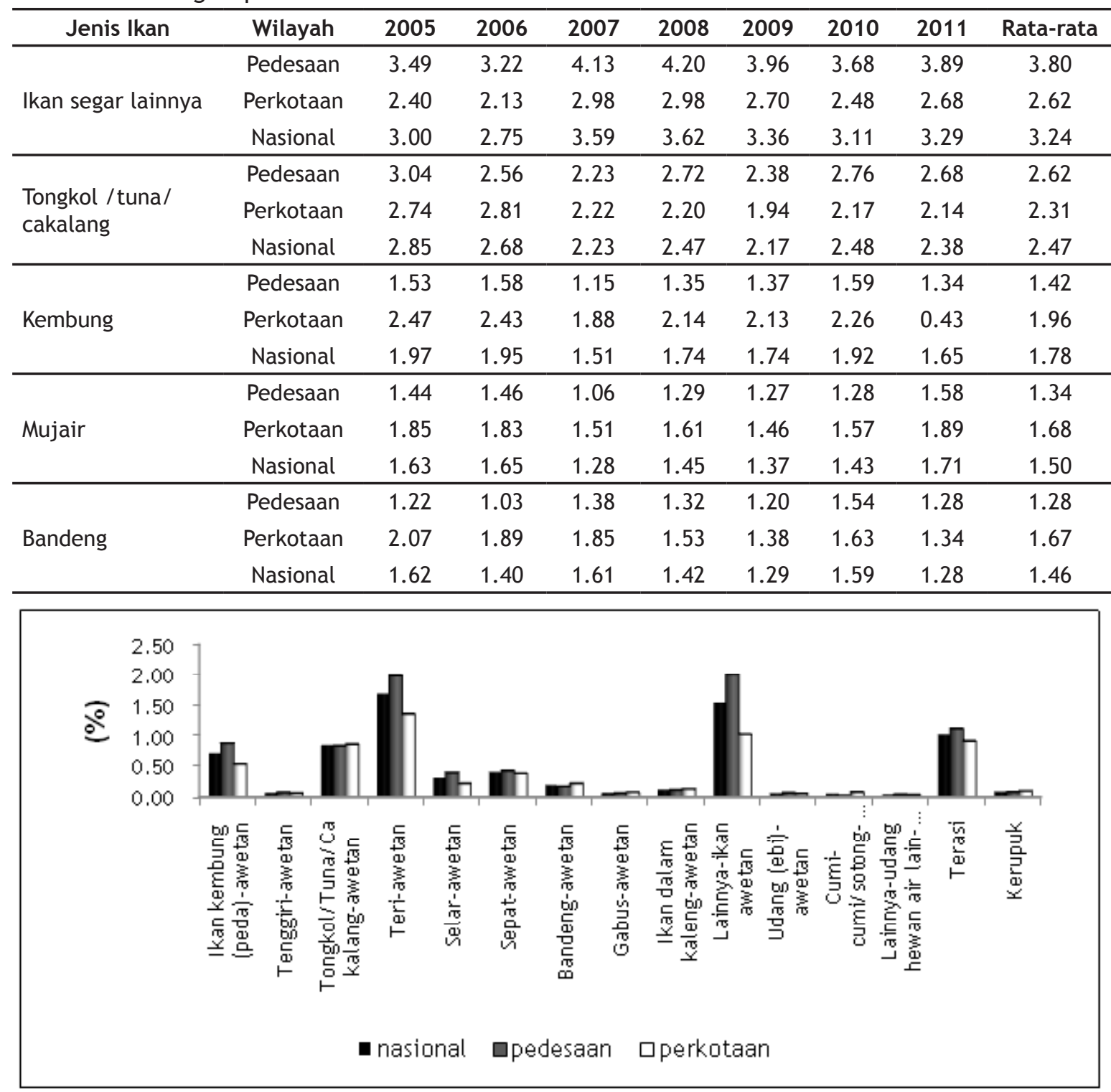

Gambar 3. Konsumsi Berbagai Jenis Ikan Olahan (kg/kapita/tahun)

an dengan konsumsi terendah di pedesaan adalah cumi-cumi/sotong awetan ( $0.02 \mathrm{~kg} / \mathrm{kapita} /$ tahun $)$ sedangkan di perkotaan adalah udang dan hewan air awetan lainnya (0.04 kg/kapita/tahun). Konsumsi ikan dari terasi lebih banyak di pedesaan $(1.12$ $\mathrm{kg} / \mathrm{kapita} /$ tahun) dibandingkan dengan perkotaan (0.92 kg/kapita/tahun). Menurut Nwabueze dan Nwabueze (2010), ikan fermentasi (terasi) merupakan sumber protein hewani yang baik.

\section{Konsumsi Ikan dari Makanan Jadi}

Makanan jadi yang diperhitungkan dalam konsumsi ikan adalah nasi campur/nasi rames dan ikan (bakar, goreng, pindang, dsb). Kedua jenis makanan ini memiliki kontribusi yang cukup besar pada konsumsi ikan sehingga harus diperhitungkan.

Berdasarkan Tabel 3 diketahui bahwa konsumsi ikan dari makanan jadi mengalami peningkat- an sejak tahun 2006. Konsumsi ikan dari kelompok makanan jadi terbesar adalah di wilayah perkotaan. Rata-rata konsumsi ikan dari makanan jadi nasional adalah $2.63 \mathrm{~kg} / \mathrm{kapita} /$ tahun. Rata-rata konsumsi ikan dari makanan jadi di pedesaan adalah $1.65 \mathrm{~kg} /$ kapita/tahun. Rata-rata konsumsi ikan dari makanan jadi di perkotaan adalah $3.71 \mathrm{~kg} / \mathrm{kapita} / \mathrm{tahun}$. Konsumsi ikan dari nasi campur/rames di perkotaan mencapai $2.90 \mathrm{~kg} / \mathrm{kapita} / \mathrm{tahun}$ dan konsumsi ikan (goreng, bakar, pindang, pepes,dsb) mencapai 0.81 $\mathrm{kg} / \mathrm{kapita} /$ tahun. Konsumsi ikan dari nasi campur/ rames di wilayah pedesaan mencapai $1.32 \mathrm{~kg} / \mathrm{kapi}$ ta/tahun dan konsumsi ikan (goreng, bakar, pindang, pepes, dsb) mencapai $0.32 \mathrm{~kg} / \mathrm{kapita} /$ tahun.

Konsumsi Ikan berdasarkan Golongan Pengeluaran Konsumsi ikan dapat dilihat berdasarkan golongan pengeluaran. Golongan pengeluaran meru- 
Tabel 3. Perkembangan Konsumsi Ikan dari Makanan Jadi (kg/kap/tahun)

\begin{tabular}{lccccccccc}
\hline \multicolumn{1}{c}{ Jenis Ikan } & Wilayah & 2005 & 2006 & 2007 & 2008 & 2009 & 2010 & 2011 & Rata-rata \\
\hline \multirow{2}{*}{ Nasi campur/ } & Pedesaan & 1.12 & 1.08 & 1.27 & 1.53 & 1.47 & 1.38 & 1.41 & 1.32 \\
rames & Perkotaan & 2.46 & 2.25 & 2.57 & 3.36 & 3.22 & 3.08 & 3.39 & 2.90 \\
& Nasional & 1.70 & 1.59 & 1.90 & 2.42 & 2.32 & 2.20 & 2.40 & 2.07 \\
\hline \multirow{2}{*}{$\begin{array}{l}\text { kan (goreng, ba- } \\
\text { kar, pindang, dsb) }\end{array}$} & Pedesaan & 0.28 & 0.26 & 0.26 & 0.37 & 0.38 & 0.39 & 0.32 & 0.32 \\
& Perkotaan & 0.48 & 0.59 & 0.67 & 0.95 & 1.04 & 1.05 & 0.88 & 0.81 \\
& Nasional & 0.37 & 0.40 & 0.45 & 0.65 & 0.70 & 0.71 & 0.59 & 0.56 \\
\hline \multirow{2}{*}{ Konsumsi makanan } \\
jadi & Pedesaan & 1.40 & 1.34 & 1.52 & 1.90 & 1.85 & 1.78 & 1.73 & 1.65 \\
& Perkotaan & 2.94 & 2.84 & 3.23 & 4.32 & 4.26 & 4.13 & 4.27 & 3.71 \\
& Nasional & 2.08 & 1.99 & 2.35 & 3.07 & 3.01 & 2.91 & 2.99 & 2.63 \\
\hline
\end{tabular}

Tabel 4. Perkembangan Konsumsi Ikan berdasarkan Golongan Pengeluaran Tahun 2005-2011 (kg/kap/th)

\begin{tabular}{cccccccccc}
\hline Golongan & Wilayah & 2005 & 2006 & 2007 & 2008 & 2009 & 2010 & 2011 & Rata-rata \\
\hline \multirow{3}{*}{1} & Nasional & 12.15 & 4.55 & 10.52 & 9.70 & 7.85 & 8.34 & 7.31 & 8.63 \\
& Pedesaan & 12.53 & 4.55 & 10.87 & 9.78 & 8.03 & 8.41 & 7.51 & 8.81 \\
& Perkotaan & 5.49 & 0.00 & 7.72 & 9.00 & 9.96 & 7.68 & 7.09 & 6.70 \\
\hline \multirow{2}{*}{2} & Nasional & 11.53 & 10.83 & 14.12 & 14.40 & 11.68 & 12.48 & 11.08 & 12.30 \\
& Pedesaan & 12.19 & 11.24 & 14.63 & 15.06 & 12.23 & 12.97 & 11.78 & 12.87 \\
& Perkotaan & 7.10 & 3.00 & 12.17 & 11.65 & 10.33 & 10.08 & 8.26 & 8.94 \\
\hline \multirow{3}{*}{3} & Nasional & 15.14 & 14.43 & 18.55 & 18.81 & 15.21 & 15.17 & 13.11 & 15.78 \\
& Pedesaan & 15.55 & 14.97 & 19.91 & 20.14 & 16.11 & 16.06 & 14.12 & 16.70 \\
& Perkotaan & 10.81 & 10.36 & 15.65 & 15.57 & 12.61 & 12.39 & 10.13 & 12.50 \\
\hline \multirow{4}{*}{4} & Nasional & 18.85 & 15.74 & 23.86 & 24.08 & 20.35 & 19.35 & 17.92 & 20.02 \\
& Pedesaan & 20.34 & 16.03 & 26.49 & 26.24 & 22.16 & 20.78 & 19.24 & 21.61 \\
& Perkotaan & 13.44 & 14.26 & 20.39 & 20.68 & 17.09 & 16.92 & 15.36 & 16.88 \\
\hline \multirow{2}{*}{5} & Nasional & 23.94 & 20.85 & 30.96 & 30.63 & 27.02 & 25.87 & 24.05 & 26.19 \\
& Pedesaan & 25.45 & 22.03 & 35.84 & 35.35 & 30.67 & 28.34 & 25.93 & 29.09 \\
& Perkotaan & 21.25 & 17.74 & 27.71 & 27.05 & 23.78 & 23.11 & 22.32 & 23.28 \\
\hline \multirow{2}{*}{6} & Nasional & 28.35 & 26.13 & 36.78 & 36.73 & 33.52 & 33.07 & 31.02 & 32.23 \\
& Pedesaan & 32.10 & 28.30 & 44.72 & 45.13 & 39.96 & 37.97 & 33.95 & 37.45 \\
& Perkotaan & 24.74 & 23.44 & 34.38 & 33.68 & 30.88 & 29.60 & 28.39 & 29.30 \\
\hline \multirow{2}{*}{7} & Nasional & 33.82 & 32.16 & 40.48 & 39.94 & 37.23 & 37.54 & 35.81 & 36.71 \\
& Pedesaan & 42.12 & 37.16 & 48.84 & 50.46 & 45.75 & 46.56 & 39.47 & 44.34 \\
& Perkotaan & 30.65 & 29.69 & 38.90 & 37.77 & 35.30 & 34.21 & 33.14 & 34.24 \\
\hline \multirow{2}{*}{8} & Nasional & 38.08 & 36.96 & 46.06 & 43.11 & 42.11 & 42.41 & 39.35 & 41.15 \\
& Pedesaan & 48.96 & 47.61 & 55.00 & 52.32 & 47.79 & 48.53 & 44.01 & 49.18 \\
& Perkotaan & 36.24 & 34.94 & 45.09 & 41.92 & 41.03 & 41.37 & 38.21 & 39.83 \\
\hline \multirow{2}{*}{8} & & & & & & & & & \\
& & & & & & &
\end{tabular}

pakan suatu pendekatan untuk membedakan tingkat pendapatan masyarakat. Berdasarkan Tabel 4 diketahui bahwa konsumsi ikan per golongan pengeluaran lebih tinggi di pedesaan dibandingkan perkotaan. Masyarakat golongan pengeluaran pertama mengonsumsi ikan dalam jumlah terendah $(8.63 \mathrm{~kg} / \mathrm{kapita} /$ tahun) dibandingkan golongan pengeluaran lainnya. Sebaliknya, masyarakat golongan pegeluaran kedelapan mengonsumsi ikan dalam jumlah tertinggi (41.15 kg/kapita/tahun) dibandingkan golongan pengeluaran lainnya. Hal ini terjadi baik di wilayah pedesaan, perkotaan maupun nasional.

Perbedaan konsumsi ikan antar golongan pengeluaran menunjukkan adanya ketidakmerataan akses sumber daya baik di pedesaan maupun perkotaan. Masyarakat yang tergolong pada penduduk miskin memiliki akses yang terbatas dibandingkan masyarakat golongan pengeluaran tinggi. Konsumsi ikan yang rendah pada masyarakat yang tergolong miskin masih jauh dari rekomendasi konsumsi ikan 
sehingga masih perlu ditingkatkan. Upaya yang dapat dilakukan pemerintah dalam meningkatkan konsumsi ikan khususnya pada penduduk miskin antara lain dengan pemerataan distribusi ikan serta peningkatan kesejahteraan khususnya nelayan. Menurut Briones et al. (2004) peningkatan konsumsi ikan perlu didukung oleh peningkatan pembangunan infrasktruktur dan peningkatan pemasaran ikan. Selain itu, mutu produk perikanan juga harus ditingkatkan. Tsuchiya (2008) menyatakan bahwa kandungan gizi dan kontaminan perlu diintegrasikan dalam panduan konsumsi ikan. Pelayanan kesehatan masyarakat dapat lebih baik dengan adanya informasi bahaya potensial dari toxicant dan manfaat gizi ketika menawarkan rekomendasi konsumsi ikan.

Masyarakat dengan golongan pengeluaran rendah mengonsumsi ikan dengan jumlah yang lebih sedikit daripada masyarakat golongan pengeluaran tinggi. Hal ini berkaitan dengan daya beli yang berbeda antar golongan pengeluaran baik di pedesaan maupun perkotaan dan sesuai dengan hasil penelitian yang dilakukan Dey et al. (2008) mengenai permintaan ikan di Asia dengan menggunakan threestage budgeting framework menunjukkan bahwa proporsi pengeluaran untuk ikan lebih banyak pada konsumen yang tergolong berpendapatan tinggi dibandingkan dengan kelompok berpendapatan rendah. Selain itu, kontribusi pengeluaran untuk ikan lebih tinggi di wilayah perkotaan dibandingkan dengan wilayah pedesaan.

\section{Rekomendasi Konsumsi Ikan}

Rekomendasi konsumsi ikan dihitung berdasarkan komposisi konsumsi energi ikan terhadap konsumsi energi pangan hewani sebesar 12\% AKE. Berdasarkan perhitungan, rekomendasi konsumsi ikan adalah $32.70 \mathrm{~kg} / \mathrm{kapita} /$ tahun atau setara dengan $89.98 \mathrm{~g} / \mathrm{kapita} / \mathrm{hari}$. Rekomendasi konsumsi ikan hasil perhitungan setara dengan $12.89 \mathrm{~g}$ protein/kapita/hari. Rekomendasi konsumsi ikan sudah dapat memenuhi $24.8 \%$ angka kecukupan protein. Hal ini menunjukkan potensi ikan yang sangat besar dalam upaya pemenuhan kecukupan protein.
Konsumsi ikan masih belum memenuhi rekomendasi konsumsi ikan. Secara nasional, rata-rata selisih antara konsumsi ikan dengan rekomendasi konsumsi ikan masih sekitar 25.6\% per tahun ( $T a-$ bel 5). Berdasarkan wilayah, konsumsi ikan perlu ditingkatkan untuk dapat memenuhi rekomendasi konsumsi ikan. Selain itu, perlu diadakan sosialisasi mengenai konsumsi ikan karena konsumsi ikan memberikan banyak manfaat bagi kesehatan. Konsumsi ikan dapat mengurangi kematian akibat kanker prostat (Szymanski et al. 2010). Perlu dukungan semua pihak agar dapat meningkatkan konsumsi ikan di Indonesia agar sesuai dengan rekomendasi konsumsi ikan. Salah satu cara yang dapat dilakukan adalah dengan mendukung program Gemarikan yang telah dicanangkan oleh Kementerian Kelautan dan Perikanan.

Rekomendasi konsumsi ikan juga dapat digunakan untuk menghitung jumlah kebutuhan ikan di Indonesia. Kebutuhan ikan diproyeksikan mencapai 8.10 juta ton pada tahun 2015. Dengan adanya angka kebutuhan konsumsi ikan ini, produksi ikan diharapkan dapat memenuhi target konsumsi ikan yang telah ditetapkan. Oleh sebab itu, Kementerian Kelautan dan Perikanan berupaya melaksanakan program untuk dapat meningkatkan produksi ikan dalam negeri untuk dapat memenuhi kebutuhan ikan pada tahun 2015. Diharapkan pemerintah dapat memprioritaskan peningkatan produksi ikan untuk dapat dikonsumsi penduduk.

\section{KESIMPULAN}

Konsumsi ikan Indonesia tahun 2005-2011 rata-rata adalah $26.04 \mathrm{~kg} / \mathrm{kapita} / \mathrm{tahun}$. Berdasarkan wilayah, konsumsi ikan masyarakat pedesaan lebih rendah dibandingkan dengan konsumsi wilayah perkotaan. Laju pertumbuhan konsumsi ikan nasional adalah $0.05 \%$ per tahun, di pedesaan $-0.05 \%$ per tahun, dan di perkotaan $0.37 \%$ per tahun. Konsumsi ikan lebih banyak berasal dari ikan segar. Konsumsi ikan dari makanan jadi lebih banyak di wilayah perkotaan dibandingkan pedesaan. Konsumsi ikan

Tabel 5. Perbandingan Konsumsi Ikan terhadap Rekomendasi Konsumsi lkan (kg/kap/th)

\begin{tabular}{ccccccc}
\hline \multirow{2}{*}{ Tahun } & \multicolumn{3}{c}{ Konsumsi Ikan } & \multicolumn{3}{c}{ Selisih (\%) } \\
\cline { 2 - 6 } & Pedesaan & Perkotaan & Nasional & Pedesaan & Perkotaan & Nasional \\
\hline 2005 & 26.40 & 26.46 & 26.34 & -23.86 & -23.58 & -24.15 \\
2006 & 24.36 & 26.21 & 25.23 & -34.24 & -24.76 & -29.61 \\
2007 & 25.15 & 26.65 & 25.88 & -30.02 & -22.70 & -26.35 \\
2008 & 27.00 & 27.23 & 27.11 & -21.11 & -20.09 & -20.62 \\
2009 & 24.87 & 25.5 & 25.18 & -31.48 & -28.24 & -29.86 \\
2010 & 25.96 & 26.56 & 26.25 & -25.96 & -23.12 & -24.57 \\
2011 & 26.06 & 26.95 & 26.27 & -25.48 & -21.34 & -24.48 \\
Rata-rata & 25.69 & 26.51 & 26.04 & -27.29 & -23.35 & -25.58 \\
\hline
\end{tabular}

* Selisih terhadap Rekomendasi Konsumsi Ikan (32.70 kg/kapita/tahun) 
berdasarkan golongan pengeluaran menunjukkan bahwa semakin besar pengeluaran maka konsumsi ikan akan semakin meningkat. Rekomendasi konsumsi ikan adalah $32.70 \mathrm{~kg} / \mathrm{kapita} /$ tahun atau mencapai 8.10 juta ton. Konsumsi ikan masih belum mencapai rekomendasi konsumsi ikan sehingga masih perlu ditingkatkan. Diperlukan penelitian lebih lanjut mengenai angka konsumsi ikan berdasarkan provinsi sehingga dapat diketahui pola konsumsi ikan di setiap wilayah.

\section{DAFTAR PUSTAKA}

Adam L. 2007. Analisis Ekonomi Perubahan pola Konsumsi Ikan di Indonesia [tesis]. Sekolah Pascasarjana Institut Pertanian Bogor, Bogor.

Briones et al. 2004. The future for fish in the food and livelihoods of the poor in Asia. NAGA, WorldFish Center Quarterly, 27(3\&4), Jul-Dec 2004.

Dahuri R. 2003. Keanakaragaman Hayati Laut: Aset Pembangunan Berkelanjutan Indonesia. Gramedia, Jakarta.

Devore et al. 2009. Dietary intake of fish and omega-3 fatty acids in relation to long-term dementia risk. American Journal Clinical Nutrition, 90, 170-6.

Dey et al. 2008. Demand for fish in Asia: a crosscountry analysis. Austr J Agr Resources Economics 52, 321-338.
Kusnadi U. 2008. Inovasi teknologi peternakan dalam sistem integrasi tanaman-ternak untuk menunjang swasembada daging sapi. Jurnal Pengembangan Informasi Pertanian, 1(3), 180-205.

Muir J. 2013. Fish, feeds and food security. Animal Frontier, 3(1), 28-24.

Nwabueze AA \& Nwabueze EO. 2010. Consumer attitude to fermented fish (Heterotis niloticus) in Ndokwa -East, Delta State, Nigeria. Agric. Biol. J. N. Am, 1(4), 694-696.

Reis LC \& Hibbeln JR. 2006. Cultural symbolism of fish and the psychotropic properties of omega-3 fatty acids. Prostaglandins, Leukotrienes and Essential Fatty Acids, 75, 227-236.

Speedy. 2003. Global production and consumption of animal source foods. J. Nutr, 2003, 133, 4048S-4053S.

Tsuchiya A et al. 2008. Fish intake guidelines: incorporating $n \_3$ fatty acid intake and contaminant exposure in the Korean and Japanese communities. Am J Clin Nutr, 87, 1867-75.

Szymanski et al. 2010. Fish consumption and prostate cancer risk: a review and meta-analysis. Am J Clin Nutr, 92, 1223-33.

Van Gelder et al. 2007. Fish consumption, n-3 fatty acids, and subsequent 5-y cognitive decline in elderly men: the Zutphen Elderly Study. Am J Clin Nutr, 85, 1142-7. 